\title{
PENGARUH KARAKTERISTIK PERUSAHAAN TERHADAP PENGUNGKAPAN AKUNTANSI SUMBER DAYA MANUSIA
}

\author{
Andarista Puji Rahayu ${ }^{1}$ \\ Ardiani Ika Sulistyawati ${ }^{2}$ \\ ardiani@usm.ac.id ${ }^{2}$ \\ Fakultas Ekonomi Universitas Semarang
}

Diterima: Mei 2019, Disetujui: Juni 2019, Dipublikasikan: Juli 2019

\begin{abstract}
Human resources is an intangible asset and is the most important factor that determines the success of the company. The role of human resources $(H R)$ in the development of the business world that is increasingly rapidly considered very important for any company. Qualified human resources will lead the organization in both comparative advantage and competitive basis and was instrumental in running the company's operations and optimally executing business strategy. This research aims to determine the effect of company size, size of board of commissioners, the concentration of ownership and status on the disclosure of accounting lisitng human resources .

Type of data used in this study is secondary data. Purposive sampling method used in sample selection. The results of this study prove that simultaneously ( $F$ est) accounting disclosure index of human resources can be explained by all the variables. While ( $t$ test) indicates that the variable board size significantly influence accounting disclosure of human resources .
\end{abstract}

Keywords :human resources accounting disclosure, company size, the concentration of ownership and listing status

\begin{abstract}
ABSTRAK
Sumber daya manusia adalah aset tidak berwujud dan merupakan faktor terpenting yang menentukan keberhasilan perusahaan. Peran sumber daya manusia (SDM) dalam pengembangan dunia bisnis yang semakin pesat dianggap sangat penting bagi perusahaan mana pun. Sumber daya manusia yang berkualitas akan memimpin organisasi dalam keunggulan komparatif dan basis kompetitif dan berperan penting dalam menjalankan operasi perusahaan dan melaksanakan strategi bisnis secara optimal. Penelitian ini bertujuan untuk mengetahui pengaruh ukuran perusahaan, ukuran dewan komisaris, konsentrasi kepemilikan dan status pengungkapan akuntansi sumber daya manusia.

Jenis data yang digunakan dalam penelitian ini adalah data sekunder. Metode pengambilan sampel Purposive digunakan dalam pemilihan sampel. Hasil penelitian ini membuktikan bahwa secara simultan indeks pengungkapan akuntansi sumber daya manusia dapat dijelaskan oleh semua variabel. Sedangkan
\end{abstract}


(uji t) menunjukkan bahwa ukuran dewan variabel berpengaruh signifikan terhadap pengungkapan akuntansi sumber daya manusia.

Kata kunci: pengungkapan akuntansi sumber daya manusia, ukuran perusahaan, konsentrasi kepemilikan dan status pencatatan

\section{PENDAHULUAN}

Sumber daya manusia merupakan aset tak berwujud dan merupakan faktor terpenting yang menentukan keberhasilan kegiatan perusahaan.Definisi sumber daya manusia menurut Wirawan (2015) adalah orang yang disebut manajer, pegawai, karyawan, buruh atau tenaga kerja yang bekerja untuk organisasi.Peranan sumber daya manusia (SDM) dalam perkembangan dunia usaha yang saat ini semakin pesat dirasa sangat penting bagi setiap perusahaan. SDM yang berkualitas akan membawa organisasi pada keunggulan baik secara komparatif maupun secara kompetitif dan sangat berperan dalam menjalankan kegiatan operasional perusahaan serta menjalankan strategi bisnis secara optimal. Dari daya pikir dan fisik yang dimiliki sumber daya manusia, maka mereka dapat menentukan kesuksesan maupun kegagalan perusahaan.

Menyadari sepenuhnya peran dominan SDM yang merupakan salah satu faktor penunjang dalam keberhasilan usaha tidak jarang terdapat beberapa perusahaan yang mengakui sumber dayanya tersebut sebagai aset dalam perusahaan, namun perusahaan tidak melaporkannya dalam laporan keuangan perusahaan. Tidak dilaporkannya SDM pada pelaporan keuangan suatu perusahaan ini lebih disebabkan karena belum adanya standar dan aturan yang mengatur mengenai pelaporan SDM dalam laporan keuangan, hal ini terjadi karena SDM itu sendiripun masih diperdebatkan oleh para ahli untuk dapat dilaporkan dalam laporan keuangan sebagai suatu aset perusahaan dan hingga saat ini pun Ikatan Akuntan Indonesia belum mengeluarkan standar yang mengatur mengenai akuntansi sumber daya manusia ini, meskipun seperti diketahui banyak sekali banyak perusahaan yang tak jarang mengakui sumber daya yang dimilikinya sebagai aset perusahaan, namun hingga saat ini pengakuan sebagai aset tersebut tidak diikuti dengan pelaporan SDM itu sendiri sebagai aset dalam laporan keuangan perusahaan. 
Kasus pelanggaran terhadap buruh sering terjadi di Indonesia Wijayanti (2011) menjelaskan bahwa telah terjadi pelanggaran hak buruh oleh oknum manajemen perusahaan. Tindakan pelanggaran oleh manajemen diantaranya mengurangi pembayaran upah dan melakukan pemutusan hubungan kerja. Peristiwa semacam ini dapat mengakibatkan demo karyawan hingga aktivitas mogok kerja. Pengungkapan akuntansi SDM didalamnya termasuk dana karyawan dan manfaat pengunduran diri (pesangon).

\section{TINJAUAN PUSTAKA}

\section{Stakeholders Theory}

Teori stakeholder menyatakan bahwa semua stakeholder mempunyai hak untuk memperoleh informasi mengenai aktivitas perusahaan yang mempengaruhi mereka.Teori stakeholder menekankan akuntabilitas organisasi jauh melebihi kinerja keuangan atau ekonomi sederhana (Deegan, 2004 dalam Widodo 2014).Teori stakeholder lebih mempertimbangkan posisi para stakeholder yang dianggap powerfull.Kelompok stakeholder inilah yang menjadi pertimbangan utama bagi perusahaan dalam mengungkapkan dan atau tidak mengungkapkan suatu informasi di dalam laporan keuangan (Ulum et al., 2008 dalam Widodo 2014).

Dalam konteks ini, para stakeholder memiliki kewenangan untuk mempengaruhi manajemen dalam proses pemanfaatan seluruh potensi yang dimiliki oleh organisasi. Karena hanya dengan pengelolaan yang baik dan maksimal atas seluruh potensi inilah organisasi akan dapat menciptakan value added untuk kemudian mendorong kinerja keuangan dan nilai perusahaan yang merupakan orientasi para stakeholder dalam mengintervensi manajemen.

\section{Agency Theory}

Agen adalah pihak yang mengelola perusahaan, lebih lanjut merupakan manajemen perusahaan.Prinsipal adalah pihak yang memiliki perusahaan, lebih lanjut adalah pemegang saham atau investor.Adanya pemisahan kepemilikan oleh prinsipal dan pengendalian oleh agen dalam sebuah organisasi cenderung menimbulkan agency conflict antara agen dan prinsipal.Teori keagenan muncul 
mengatasi konflik tersebut. Jensen dan Meckling (1976) dalam Widodo dan Widagdo (2015) mengemukakan bahwa hubungan keagenan antara prinsipal dan agen diinterpretasikan sebagai suatu kontrak, dimana prinsipal atau pemberi kerja memperkerjakan agen untuk pemenuhan sejumlah jasa dan melimpahkan wewenang dalam pengambilan keputusan.

Manajer sebagai pihak yang mengelola kegiatan perusahaan sehari-hari memiliki lebih banyak informasi internal dibandingkan pemilik (pemegang saham).Manajer berkewajiban untuk memberikan sinyal mengenai kondisi perusahaan kepada pemilik.Sinyal yang diberikan dapat dilakukan melalui pengungkapan informasi akuntansi seperti laporan keuangan.Laporan keuangan tersebut penting bagi para pengguna informasi eksternal terutama karena kelompok ini berada dalam kondisi yang paling besar ketidakpastiannya (Ali, 2002 dalam Setyaningrum, 2013).

\section{Akuntansi Sumber Daya Manusia}

Menurut Flamholtz dalam Siregar (2012) dalam bukunya "Human Resource Accounting” (1977), dikemukakan sebagai berikut:

"Human Resource Accounting means accounting for people as an organizational resources".Artinya: "Akuntansi Sumber Daya Manusia berarti akuntansi untuk manusia sebagai suatu sumber dari organisasi”.

The Committee on Human Resources Accouting dan AAA (Belkaoui, 1995) dalam Naukoko, (2014) mendefinisikan ASDM sebagai suatu proses mengidentifikasikan dan mengukur data tentang sumber daya manusia dan menyampaikan informasi ini kepada mereka yang berkepentingan. Belkaoui (1995) dalam Naukoko, (2014) mendefinisikan ASDM sebagai suatu proses mengidentifikasi, mengukur data tentang SDM dan mengkomunikasikan informasi ini kepada pihak yang berkepentingan.Definisi Belkaoui berarti ASDM bertujuan untuk mengidentifikasikan nilai SDM, mengukur biaya dan nilai manusia yang dikontribusikan kepada perusahaan, dan mengkaji pengaruh pemahaman informasi ini dan dampaknya pada perilaku manusia.(Harahap, 2007 dalam Naukoko, 2014). 
Pandangan lainnya mengenai ASDM dikemukakan oleh Brummed, dimana Brummed melihat ASDM sebagai suatu konsep yang meliputi sumber daya manusia sebagai aktiva, penentuan biaya yang diinvestasikan dan hubungannya dengan biaya-biaya hasil pakai, estimasi dan menyediakan ketelitian ekonomi tentang nilai sumber daya manusia dalam organisasi (Brummet, 1995 dalam Naukoko 2014). Sedangkan menurut Lako (1995) dalam Naukoko, (2014): ASDM adalah sebuah proses pengidentifikasi dan pengukuran data tentang sumber daya manusia dan pengomunikasiannya atas informasi-informasi yang termasuk di dalamnya kepada pihak-pihak yang berkepentingan.

Berdasarkan pada beberapa definisi ASDM yang telah dikemukakan sebelumnya, ASDMdapat disimpulkan sebagai suatu bidang ilmu akuntansi yang berfokus pada manusia sebagaisumber daya organisasi.Sebagai sumber daya organisasi, SDM harus dapat diukur dandilaporkan.Pengukuran yang digunakan dalam ASDM bukanlah berdasarkan pada biayaoperasional saja, tetapi sebagai biaya atau pengeluaran modal. Oleh karena itu, SDM dalam suatuperusahaan harus dapat dinilai sejak proses penyeleksian, perekrutan, pelatihan danpengembangan kemampuan pegawai agar dapat diketahui perkembangan dari nilai SDM sebagaiasset dalam suatu organisasi dalam suatu periode tertentu.

\section{Perumusan Hipotesis}

\section{Pengaruh size terhadap pengungkapan akuntansi sumber daya manusia}

Ketersediaan dana dan sumber daya yang besar membuat perusahaan merasa perlu untuk melakukan pengungkapan akuntansi sumber daya manusianya. Perusahaan berukuran besar mendapatkan permintaan yang besar dari publik akan informasi yang lebih lengkap. Perusahaan dengan ukuran lebih besar akan lebih terlihat dan menarik perhatian dari parastakeholder.

Variabel ukuran perusahaan dapat dilihat dengan mengukur nilai total asset yang dimiliki perusahaan tersebut.Studi yang berkaitan dengan pengungkapan keuangan mengungkapkan bahwa ada hubungan positif antara ukuran perusahaan dan jumlah pengungkapan. Berdasarkan uraian diatas maka hipotesis yang dapat dirumuskan adalah , $\mathrm{H}_{1}$ :Sizeberpengaruh positif terhadap pengungkapan akuntansi SDM. 


\section{Pengaruh ukuran dewan komisaris terhadap pengungkapan akuntansoi sumber daya manusia}

Berkaitan dengan teori keagenan, dengan melaporkan laporan keuangan yang lebih lengkap maka setidaknya manajemen dapat mengurangi masalah keagenan yang rawan muncul dalam hubungan manajer - pemegang saham, semakin besar jumlah anggota dewan komisaris, maka semakin mudah untuk mengendalikan CEO dan pengawasan yang dilakukan akan semakin efektif. Dikaitkan dengan pengungkapan akuntansi sumber daya manusia perusahaan, maka tekanan terhadap manajemen juga akan semakin besar untuk mengungkapkannya.

Hal ini sejalan dengan hasil penelitian yang dilakukan oleh Maria Ulfa (2016) bahwa ukuran dewan komisaris berpengaruh terhadap pengungkapan akuntansi sumber daya manusia. Berdasarkan uraian diatas maka hipotesis yang dapat dirumuskan adalah :

$\mathrm{H}_{2}=$ Ukuran dewan komisaris berpengaruh positif terhadap pengungkapan akuntansi sumber daya manusia.

\section{Pengaruh konsentrasi kepemilikan terhadap pengungkapan akuntansi sumber daya manusia}

Konsentrasi kepemilikan adalah sejumlah saham perusahaan yang tersebar dan dimiliki oleh beberapa pemegang saham yang nantinya pihak manajemen berkewajiban melaporkannya untuk beberapa kepentingan antara lain : perbaikan kebijakan perusahaan di masa mendatang dan pengambilan keputusan oleh pemegang saham RUPS (Istanti, 2009 dalam Puasanti, 2013). Kepemilikan dikatakan terkonsentrasi jika sebagian besar saham dimiliki oleh sebagian kecil individu atau kelompok sehingga pemegang saham tersebut memiliki jumlah saham yang relative dominan dibandingkan pemegang saham lainnya. Sedangkan kepemilikan dikatakan terdiversifikasi apabila saham perusahaan dimiliki oleh banyak pemegang saham dengan jumlah saham yang relative sama sehingga tidak ada pemegang saham yang dominan terhadap pemegang saham lainnya karena memiliki kontrol yang sama besar (Yustiana, 2014).Dengan demikian terkonsentrasinya kepemilikan perusahaan akan menimbulkan kontrol pada 
pemilik saham mayoritas dan bisa mempengaruhi kebijakan menejemen melalui hak suara.

Darmawati (2006) dalam Puasanti (2013), menyebutkan dengan semakin terkonsentrasinya kepemilikan perusahaan, maka pemegang saham mayoritas akan semakin menguasai perusahaan dan semakin berpengaruh terhadap pengambilan keputusan. Shleifer dan Wolfenzon (dalam Puasanti, 2013), menyatakan bahwa dengan lemahnya sistem hukum atau proteksi terhadap investor, maka konsentrasi kepemilikan menjadi alat yang lebih penting untuk mengatasi masalah-masalah keagenan.Berdasarkan asumsi tersebut, maka hipotesis yang dapat dirumuskan adalah sebagai berikut,

$\mathrm{H}_{3}=$ Konsentrasi kepemilikan berpengaruh negatif terhadap pengungkapan akuntansi SDM.

\section{Pengaruh listing status terhadap pengungkapan akuntansi sumber daya manusia}

Listing statusdibedakanke dalam dua bentuk yaitulisted dan unlisted compa-nies.Listed companies adalah perusahaan - perusahaan yang memperdagangkan saham baik di New York Stock Exchange (NYSE) maupun di American Stock Exchange (AMEX).Sebaliknya, unlisted companies adalah perusahaan-perusahaan yang memperdagangkan saham di the Over-the-Counter (OTC) market.

Williams (2001) menemukan adanya hubungan positif antara perusahaanperusahaan yang listing di luar negeri (multiple listing) dengan jumlah pengungkapan informasi.Semakin banyak listing status yang dimiliki perusahaan semakin tinggi tingkat pengungkapan informasi dalam laporan tahunan.Berdasarkan uraian diatas maka hipotesis yang dapat dirumuskan adalah : $\mathrm{H}_{4}=$ Listing status berpengaruh positif terhadap pengungkapan akuntansi sumber daya manusia. 


\section{METODOLOGI PENELITIAN}

\section{Populasi dan Penentuan Sampel}

Populasi dalam penelitian ini adalah seluruh sector perusahaan yang telahterdaftar di Bursa Efek Indonesia (BEI). Pemilihan seluruh sector perusahaan sebagai objek penelitian dikarenakan belum ada penelitian terdahulu yang menggunakan seluruh sector perusahaan sebagai objek penelitian.

Pemilihan sampel perusahaan dalam penelitian ini menggunakan metode purposive sampling, artinya adalah bahwa populasi yang akan dijadikan sampel dalam penelitian ini adalah populasi yang memenuhi criteria sampel tertentu sesuai dengan yang dikehendaki peneliti (Sekaran, 2006).

Kriteria pengambilan sampel dalam penelitian ini adalah sebagai berikut :

1. Perusahaan seluruh sektor yang terdaftar di BEI tahun 2012-2014.

2. Perusahaan yang konsisten menerbitkan laporan keuangan di situs resmi BEI selama tahun 2012-2014.

3. Perusahaan memiliki laba yang positif

4. Perusahaan memiliki pemegang saham terbesar minimal sebesar $50 \%$.

5. Perusahaan tidak mengalami delisting dari Bursa Efek Indonesia.

\section{Jenis dan Sumber Data}

Data yang digunakan dalam penelitian ini adalah data sekunderberupalaporan keuangan perusahaan periode 2012-2014. Data tersebut diperoleh dari situs BEI (Bursa Efek Indonesia) yaitu www.idx.co.id atau website resmi dari masing-masing perusahaan.

\section{Metode Pengumpulan Data}

Metode pengumpulan data yang digunakan dalam penelitian ini adalah studi pustaka, yaitu diperoleh dari beberapa literatur yang berkaitan dengan masalah yang sedang diteliti. Data yang digunakan dalam penelitian ini dikumpulkan dengan metode dokumentasi. 


\section{MetodeAnalisis Data}

Model persamaan regresi dalam penelitian ini adalah sebagai berikut :

$\mathrm{Y}=\alpha+\beta_{1} \mathrm{SIZE}+\beta_{2} \mathrm{COMM}-\beta_{3} \mathrm{OWN}+\beta_{4} \mathrm{LST}+\varepsilon$

Dimana :

$\mathrm{Y}=$ Pengungkapan Akuntansi SDM

$\alpha=$ Konstanta (tetapan)

$\beta_{1}-\beta_{4}=$ Koefisien variabel independen apabila nilai $\beta$ positif maka akan terjadi kenaikan pada variabel dependen dan sebaliknya.

SIZE $=$ Ukuran Perusahaan

$\mathrm{COMM}=$ Ukuran Dewan Komisaris

OWN $=$ Konsentrasi Kepemilikan

LST = Listing Status

$\varepsilon=$ Error

\section{HASIL DAN PEMBAHASAN}

Hasil analisis regresi linier berganda antara HRAD atau pengungkapan akuntansi sumber daya manusia (Y) dengan dengan SIZE atau ukuran perusahaan $\left(\mathrm{X}_{1}\right)$, ukuran dewan komisaris $\left(\mathrm{X}_{2}\right)$, konsentrasi kepemilikan $\left(\mathrm{X}_{3}\right)$ dan listing status $\left(\mathrm{X}_{4}\right)$ yang telah diolah dengan SPSS 20 adalah sebagai berikut :

Tabel 1

Analisis Regresi Linier Berganda

\begin{tabular}{|c|c|c|c|c|c|c|c|c|}
\hline \multirow{2}{*}{\multicolumn{2}{|c|}{ Model }} & \multicolumn{2}{|c|}{$\begin{array}{l}\text { Unstandardized } \\
\text { Coefficients }\end{array}$} & \multirow{2}{*}{\begin{tabular}{|c|}
$\begin{array}{c}\text { Standardiz } \\
\text { ed } \\
\text { Coefficien } \\
\text { ts }\end{array}$ \\
Beta
\end{tabular}} & \multirow[t]{2}{*}{$\mathrm{t}$} & \multirow[t]{2}{*}{ Sig. } & \multicolumn{2}{|c|}{$\begin{array}{l}\text { Collinearity } \\
\text { Statistics }\end{array}$} \\
\hline & & B & Std. Error & & & & $\begin{array}{l}\text { Toleran } \\
\text { ce }\end{array}$ & VIF \\
\hline \multirow{5}{*}{1} & $\begin{array}{l}\text { (Consta } \\
\text { nt) }\end{array}$ & 12.460 & 22.944 & & .543 & .588 & & \\
\hline & SIZE & .254 & .809 & .035 & .314 & .754 & .599 & 1.670 \\
\hline & COMM & 4.020 & .917 & .492 & 4.384 & .000 & .587 & 1.703 \\
\hline & OWN & 0.000051 & .096 & .000 & -.001 & 1.000 & .949 & 1.054 \\
\hline & LST & -1.017 & 4.161 & -.021 & -.244 & .807 & .980 & 1.021 \\
\hline
\end{tabular}

a. Dependent Variable: HRAD

Sumber : data sekunder diolah dengan SPSS 20, 2016. 
Berdasarkan output SPSS pada tabel 4.6 diatas maka persamaan model analisis regresi berganda yang diperoleh adalah sebagai berikut :

$$
\mathrm{Y}=0,035 \mathrm{X}_{1}+0,492 \mathrm{X}_{2}+0,000 \mathrm{X}_{3}-0,021 \mathrm{X}_{4}+\mathrm{e}
$$

\section{Pengujian Hipotesis Pertama}

SIZE atau ukuran perusahaan mempunyai $\mathrm{t}$ hitung 0,314 dan $\mathrm{t}$ tabel 1,98422 dimana 0,314<1,98422 dengan nilai signifikan 0,05 atau 5\%. Nilai signifikan yang lebih besar dari 0,05 yaitu sebesar 0,754 maka ini menunjukkan bahwa SIZE atau ukuran perusahaan tidak berpengaruh terhadap pengungkapan akuntansi sumber daya manusia yang berarti bahwa $\mathrm{H}_{1}$ ditolak.

Pengujian Hipotesis Kedua

COMM atau ukuran dewan komisaris mempunyai t hitung 4,384 dan $\mathrm{t}$ tabel 1,98422 dimana 4,384>1,98422 dengan nilai signifikan 0,05 atau 5\%. Nilai signifikan yang lebih kecil dari 0,05 yaitu sebesar 0,000 maka ini menunjukkan bahwa ukuran dewan komisaris berpengaruh serta signifikan terhadap pengungkapan akuntansi sumber daya manusia yang berarti bahwa $\mathrm{H}_{2}$ diterima.

\section{Pengujian Hipotesis Ketiga}

OWN atau konsentrasi kepemilikan mempunyai t hitung -0,001 dan t tabel 1,98422 dimana $-0,001<1,98422$ dengan nilai signifikan 0,05 atau 5\%. Nilai signifikan yang lebih besar dari 0,05 yaitu sebesar 1,000 maka ini menunjukkan bahwa konsentrasi kepemilikan tidak berpengaruh terhadap pengungkapan akuntansi sumber daya manusia yang berati bahwa $\mathrm{H}_{3}$ ditolak.

Pengujian Hipotesis Keempat

LST atau listing status mempunyai t hitung -0,244 dan t tabel 1,98422 dimana $-0,244<1,98422$ dengan nilai signifikan 0,05 atau 5\%. Nilai signifikan yang lebih besar dari 0,05 yaitu 0,807 maka ini menunjukkan bahwa listing status tidak berpengaruh terhadap pengungkapan akuntansi sumber daya manusia yang berarti bahwa $\mathrm{H}_{4}$ ditolak. 
Hasil Pengujian Koefisien Determinasi

\section{Tabel 2}

Koefisien Determinasi

\begin{tabular}{|l|r|r|r|r|r|}
\hline $\begin{array}{l}\text { Mode } \\
1\end{array}$ & R & R Square & $\begin{array}{c}\text { Adjusted R } \\
\text { Square }\end{array}$ & $\begin{array}{c}\text { Std. Error of } \\
\text { the Estimate }\end{array}$ & $\begin{array}{c}\text { Durbin- } \\
\text { Watson }\end{array}$ \\
\hline 1 & $.516^{\mathrm{a}}$ & .266 & .237 & 14.75664 & 1.898 \\
\hline
\end{tabular}

a. Predictors: (Constant), LST, COMM, OWN, SIZE

b. Dependent Variable: ABS_HRAD

Sumber : data sekunder diolah dengan SPSS 20, 2016.

Dari tabel 2 diatas didapatkan nilai Adjusted $R$ Square sebesar 0,237, hal ini berarti bahwa 23,7 persen variasi pengungkapan akuntansi sumber daya manusia dapat dijelaskan oleh variabel bebas yaitu SIZE atau ukuran perusahaan, ukuran dewan komisaris, konsentrasi kepemilikan dan listing status. Sedangkan sisanya 76,3 persen dijelaskan oleh sebab - sebab yang lain di luar model atau selain keempat variabel tersebut.

\section{Pembahasan}

Hasil uji statistik t menghasilkan nilai t hitung sebesar 0,314 dan nilai signifikansi sebesar 0,588 yang lebih besar dari tingkat signifikansinya $(\alpha)$ yaitu 0,05. Hasil tersebut membuktikan bahwa ukuran perusahaan tidak berpengaruh terhadap pengungkapan akuntansi SDM.Sehingga hipotesis pertama dalam penelitian ini ditolak. Hasil penelitian ini konsisten dengan penelitian yang dilakukan oleh Cristy (2015) dan Setiawan (2016), akan tetapi bertentangan dengan penelitian yang dilakukan oleh Al Mamun (2009), Alam dan Deb (2010), Wardini dan Muktiyantio (2010) dalam Ulfa (2016) dan Widodo (2014) yang menyatakan bahwa ukuran perusahaan berpengaruh terhadap pengungkapan akuntansi sumber daya manusia.

Hasil uji statistik t menghasilkan nilai t hitung sebesar 4,384 dan nilai signifikan sebesar 0,000 yang lebih kecil dari tingkat signifikansinya $(\alpha)$ yaitu 0,05. Hasil tersebut membuktikan bahwa ukuran dewan komisaris berpengaruh positif terhadap pengungkapan akuntansi SDM.Sehingga hipotesis kedua dalam 
penelitian ini diterima.Hal ini konsisten dengan penelitian yang dilakukan oleh Ulfa (2016), Chakroun (2008), Nurknin (2009), Waryanto (2010) dalam Wahyuningtyas dan Nugrahanti (2012).Dewan komisaris dipersepsikan sebagai salah satu alat monitoring yang efektif terhadap perilaku pada pengendalian dan pengawasan terhadap pihak manajemen dalam operasi perusahaan, salah satunya adalah pengungkapan akuntansi sumber daya manusia. Sehingga pada akhirnya tujuan perusahaan untuk memperoleh legitimasi dari stakeholdersmelalui pengungkapan akuntansi sumber daya manusia dapat diperoleh.

Hasil uji statistik t menghasilkan nilai t hitung sebesar $-0,001$ dan nilai signifikan sebesar 1,000 yang lebih besar dari tingkat signifikansi $(\alpha)$ yaitu 0,05 . Hasil tersebut membuktikan bahwa konsentrasi kepemilikan tidak berpengaruh terhadap pengungkapan akuntansi SDM.Sehingga hipotesis ketiga dalam penelitian ini ditolak. Hasil penelitian ini konsisten dengan penelitian yang dilakukan oleh Alam dan Deb (2010) dan Dominguez (2012) dalam Ulfa (2016), Putri (2013) dalam Kurniawati (2015) dan Chen et al., (2007) dalam Widodo dan Widagdo (2014), akan tetapi bertentangan dengan penelitian yang dilakukan oleh Artinah (2013) dalam Faradina (2015) yang menyatakan bahwa konsentrasi kepemilikan berpengaruh terhadap pengungkapan akuntansi sumber daya manusia.

Hasil uji statistik t menghasilkan nilai t hitung sebesar -0,244 dan nilai signifikan sebesar 0,807 yang lebih besar dari tingkat signifikansi $(\alpha)$ yaitu 0,05 . Hasil tersebut membuktikan bahwa lisitng status tidak berpengaruh terhadap pengungkapan akuntansi SDM.Sehingga hipotesis keempat dalam penelitian ini ditolak. Hal ini bertentangan dengan penelitian yang dilakukan oleh Athanasios et al., (2013) dalam Ulfa (2016) yang menyatakan bahwa listing status berpengaruh terhadap pengungkapan akuntansi sumber daya manusia.

\section{PENUTUP}

\section{Kesimpulan}

Berdasarkan hasil analisis data dan pembahasan hasil penelitian terhadap hipotesis yang telah dirumuska, maka dappat dibuat kesimpulan sebagai berikut : 
a. SIZE atau ukuran perusahaan tidak berpengaruh terhadap pengungkapan akuntansi sumber daya manusia.

b. Ukuran dewan komisaris berpengaruh signifikan terhadap pengungkapan akuntansi sumber daya manusia.

c. Konsentrasi kepemilikan tidak berpengaruh terhadap pengungkapan akuntansi sumber daya manusia.

d. Listing status tidak berpengaruh terhadap pengungkapan akuntansi sumber daya manusia.

e. Secara simultan, hasil penelitian menunjukkan bahwa SIZE atau ukuran perusahaan, ukuran dewan komisaris, konsentrasi kepemilikan dan listing status secara bersama - sama berpengaruh signifikan terhadap pengungkapan akuntansi sumber daya manusia.

f. Nilai Adjusted $R$ Square sebesar 0,237, hal ini berarti bahwa 23,7 persen variasi pengungkapan akuntansi sumber daya manusia dapat dijelaskan oleh variasi dari 4 variabel bebas yaitu SIZE atau ukuran perusahaan, ukuran dewan komisaris, konsentrasi kepemilikan dan listing status. Sedangkan sisanya Sedangkan sisanya 76,3 persen dijelaskan oleh sebab sebab yang lain di luar model atau selain keempat variabel tersebut.

\section{Saran}

1. Bagi perusahaan, perusahaan harus lebih terbuka lagi dalam pengungkapan akuntansi sumber daya manusianya agar informasi yang disajikan kepada para investor semakin luas dan lengkap.

2. Bagi investor maupun calon investor seharusnya lebih memperhatikan lagi faktor - faktor yang dapat mempengaruhi pengungkapan akuntansi sumber daya manusia selain SIZE atau ukuran perusahaan, ukuran dewan komisaris, konsentrasi kepemilikan dan listing status. Bisa juga dilihat dari laporan keuangan perusahaan. 


\section{DAFTAR PUSTAKA}

Agustina, L. (2012). Pengaruh karakteristik perusahaan terhadap pengungkapan laporan tahunan. Jurnal dinamika akuntansi, 4(1).

Cendika, F. B., \& Sawarjuwono, T. (2014).Metode Valuasi Human Capital dalam Konsep Human Resource Accounting (HRA) dan Pengungkapannya.Simposium Nasional Akuntansi XVII Lombok.

Cristy, Nia Br. P. (2015). Pengaruh Karakteristik Perushaaan Terhadap Pengungkapan Akuntansi Sumber Daya Manusia Pada Perusahaan Manufaktur Yang Terdaftar Di Bursa Efek Indonesia Tahun 2011 2013.Jurnal Online Mahasiswa FEKON. Vol. 2, No. 2.

Faradina, S. (2015).Faktor-faktor yang mempengaruhi pengungkapan intellectual capital pada perusahaan property dan real estate yang terdaftar di Bursa Efek Indonesia tahun 2010-2014.Jurnal Bisnis dan Manajemen.Vol. 5.No. 2.

Imam, G. (2011).Aplikasi Analisis Multivariate dengan Program SPSS. Semarang: Badan Penerbit Universitas Diponegoro.

Laksmitaningrum C. F., \& Purwanto, A. (2013).Analisis Pengaruh Karakteristik Perusahaan, Ukuran Dewan Komisaris dan Struktur Kepemilikan Terhadap Pengungkapan CSR (Studi Empiris pada Perusahaan Manufaktur Yang Terdaftar Di Bursa Efek Indonesia Tahun 20092011)Jurnal Akuntansi Diponegoro. Vol. 2 No.2.

Nuryaman, N. (2009). Pengaruh Konsenterasi Kepemilikan, Ukuran Perusahaan, dan Mekanisme Corporate Governance Terhadap Pengungkapan Sukarela. Jurnal Akuntansi dan Keuangan Indonesia, 6(1), 89-116.

Purnomosidhi, B. (2005). Analisis Empiris Terhadap Determinan Praktik Pengungkapan Modal Intelektual Pada Perusahaan Publik di BEJ. TEMA (Telaah Ekonomi, Manajemen, dan Akuntansi), 6(2).

Putri, R. P. M., \& Raharja, S. (2013). Dampak Pengungkapan Sumber Daya Manusia terhadap Reputasi Perusahaan. Universitas Diponegoro, Jurnal Fakultas Ekonomika dan Bisnis.

Rahayu, A. W. W., \& Affandy, D. P. (2012).Analisis Penerapan Akuntansi Sumber Daya Manusia terhadap Perbandingan Kinerja Laporan Keuangan pada PT. BPRS Mitra Harmoni Malang. Jurnal Ilmiah Mahasiswa $F E B, 1(1)$.

Sembiring, E. R. (2006). Karakteristik perusahaan dan pengungkapan tanggung jawab sosial: study empiris pada perusahaan yang tercatat di Bursa Efek Jakarta. MAKSI, 6. 
Setiawan, H., \& Wahyono, A. (2016).Pengaruh Ukuran Perusahaan, Umur Perusahaan, Diversifikasi Produk Dan Return On Assets Terhadap Pengungkapan Akuntansi Sumber Daya Manusia (Studi Pada Perusahaan Perbankan Dan Asuransi Yang Terdaftar Di Bursa Efek Indonesia Periode 2011-1014) (Doctoral dissertation, Universitas Muhammadiyah Surakarta).

Sudarno, S. (2010). Akuntansi Sumber Daya Manusia: Perlakuan Dan Pengukuran. Jurnal Akuntansi Universitas Jember, 8(1).

Sutanto, F. D. (2012). Pengaruh Karakteristik Perusahaan Terhadap Tingkat Pengungkapan Informasi Intellectual Capital di dalam Laporan Tahunan (Studi pada Industri Manufaktur yang Terdaftar di Bursa Efek Indonesia Tahun 2009).

Syarif, F. (2013).Perkembangan Akuntansi Sumber Daya Manusia Di Dunia Internasional.Jurnal Akuntansiku, 1(1).

Ulfa, M. (2016). Pengaruh Karakteristik Perusahaan terhadap Pengungkapan Akuntansi Sumber Daya Manusia (Studi Empiris pada Perusahaan Sektor Keuangan, IT, dan Farmasi Terdaftar di Bursa Efek Indonesia Tahun 2013 Dan 2014).Jember: Jurnal FE Universitas jember.

Ulum, I., \& Novianty, N. (2005).Analisis Faktor-Faktor yang Mempengaruhi Pengungkapan Intellectual Capital pada Official Website Perguruan Tinggi Indonesia. Jurnal Universitas Muhammadiyah Malang.

Utami, S., \& Prastiti, S. D. (2011).Pengaruh karakteristik perusahaan terhadap social disclosure. Jurnal Ekonomi Bisnis, TH, 16.

Widodo, N. M. (2014). Pengaruh Karakteristik Perusahaan terhadap Pengungkapan Akuntansi Sumber Daya Manusia.SNA XVII Mataram.

Widodo, N. M., \& Widagdo, A. K. (2015). Struktur Kepemilikan Terhadap Pengungkapan Akuntansi Sumber Daya Manusia. Sustainable Competitive Advantage (SCA), 5(1).

http://print.kompas.com/baca/2015/04/30/Praktik-Korupsi-Masih-Menggerogoti-

\section{Hak-Buruh.}


Majalah Ilmiah Solusi

Vol. 17, No. 3 Juli 2019

ISSN : 1412-5331

Halaman ini sengaja dikosongkan 